Portland State University

PDXScholar

\title{
Situating HIV/AIDS Humanitarian Film in the National Cinema Culture of Mozambique: Historical, Contemporary and Feminist Perspectives
}

Sebastián Andrés Suárez Hode

Portland State University

Follow this and additional works at: https://pdxscholar.library.pdx.edu/honorstheses

Part of the African Studies Commons, Film and Media Studies Commons, Other Feminist, Gender, and Sexuality Studies Commons, and the Race, Ethnicity and Post-Colonial Studies Commons Let us know how access to this document benefits you.

\section{Recommended Citation}

Suárez Hode, Sebastián Andrés, "Situating HIV/AIDS Humanitarian Film in the National Cinema Culture of Mozambique: Historical, Contemporary and Feminist Perspectives" (2021). University Honors Theses. Paper 1038.

https://doi.org/10.15760/honors.1064

This Thesis is brought to you for free and open access. It has been accepted for inclusion in University Honors Theses by an authorized administrator of PDXScholar. Please contact us if we can make this document more accessible: pdxscholar@pdx.edu. 
Situating HIV/AIDS Humanitarian Film in the National Cinema Culture of Mozambique: Historical, Contemporary and Feminist Perspectives

by

Sebastián Andrés Suárez Hode

An undergraduate honors thesis submitted in partial fulfillment of the requirements for the degree of

Bachelor of Arts

in

University Honors

and

Film

Thesis Adviser

Mark Berrettini

Portland State University 


\section{ABSTRACT}

The HIV/AIDS epidemic in Mozambique has enabled a new wave of humanitarian cinema that seeks to educate and empower a population that has been adversely affected by it. Moreover, a legacy of colonial-era patriarchal systems has resulted in contemporary Mozambican women being disproportionately impacted by the virus. Cognisant of this disparity and intersected social issues, humanitarian projects have incorporated film production and distribution as a vehicle for cinematic explorations of Mozambican women's subjectivities, making way for an especially feminist reconditioning of national cinema culture. This essay will explain how HIV/AIDS cinema finds its place within the larger discourse of national Mozambican cinema by demonstrating how the body of films that comprise it are successful in their nuanced depictions of Mozambican subjectivities. Besides offering epidemiological pedagogy, the films address the Mozambican spectator with an almost explicit feminist message and are simultaneously concious of domestic social issues such as disparities in levels of poverty and education, entrenched gender norms, sex work, migration and cross-generational hierarchies. Furthermore, this essay will theorize a nascent Mozambican women's cinema first by illustrating the way images of women were used historically to foster a flawed homogenous, postgender and postcolonial national identity during the development of Mozambican national cinema.

Understanding this historical context, in turn, will facilitate my argument that the new landscape of HIV/AIDS humanitarian cinema has contributed to the freedom for Mozambican women and feminist filmmakers to produce refined representations of Mozambican women's subjectivities that explicitly tackle patriarchal society. 
Situating HIV/AIDS Humanitarian Film in the National Cinema Culture of Mozambique: Historical, Contemporary and Feminist Perspectives

\section{INTRODUCTION}

Mozambique has a unique relationship with film that has remained mostly unexplored in larger inquiries of African cinema. After gaining independence from Portugal in 1975, film production immediately became important for the newfound country's liberation movement and its attempts to foster a homogenised national Mozambican identity thereafter. The cinema traditions of Mozambique's liberation struggle and independence movement present several unique aspects of moving image production that continue to inform contemporary mechanisms of Mozambican cinema production, distribution, writing and spectatorship. Additionally, present day factors related to socioeconomic conditions, public health crises, gender disparity and technological development have introduced new and rapidly evolving processes, priorities and limitations for national Mozambican cinema production and distribution. One of the more significant ongoing crises that have profoundly influenced the country's national cinema is the advent of HIV/AIDS.

Sub Saharan Africa, which has been dubbed the "AIDS belt," is the global region most affected by the epidemiological crisis. Although the viral infection touches virtually every corner of the globe, the World Health Organization categorizes its spread not as a global pandemic, but rather, and seemingly paradoxical, as a global epidemic. The term "pandemic" refers to a disease that spreads over multiple countries and continents, while an "epidemic" is a disease that affects 
individuals within a community, country or region (WHO | Definitions: emergencies 2014). The World Health Organization's dubbing of the HIV/AIDS crisis as a global epidemic does not disavow its worldwide spread. Instead, this terminology accounts for the contemporary disparities amongst populations across the globe such as sustainable access to antiretroviral medication, gender inequality, public health education, local stigmas and sexual practices. This categorization speaks not only to the disparity of how some regions are affected more than others, but also to the need to approach prevention and mitigation with a consideration of regional, cultural and national specificity. Even within national and regional borders, there exist vast differences in how the disease spreads and the tactics needed to curb it. Marco Antonio Vieria explains this in his inquiry into distinct responses implemented for HIV/AIDS across three Southern African nations (Botswana, South Africa and Mozambique), where, despite the "intrinsic universal value of certain types of international norms (such as international human rights norms)... [HIV/AIDS mitigation and prevention] depend on variations in the domestic structure of states, [therefore], securitisation attempts can be integrally accepted (Botswana), instrumentally used (Mozambique), or totally rejected (South Africa)" (Vieira 2011, page 28). Mozambican governmental institutions, NGO's and religious organizations working across the country to tackle the epidemiological crisis have progressively adopted a uniquely Mozambican approach, and this nationalized approach has yielded a wave of film productions reminiscent of the country's national cinema origins: moving images produced for Mozambican audiences with a purpose of social action and mobilization, funded and aided by international players that are ultimately attentive to the national context. 
This thesis will attempt to situate the wave of contemporary HIV/AIDS films into the discourse of national Mozambican cinema by drawing parallels to preceding revolutionary cinema traditions, including Mozambique's transnational approach to film production, its model of film distribution within urban and rural settings, and the uniquely-Mozambican spectatorial objectives. Moreover, with an understanding of the gendered disparities in HIV/AIDS prevalence rates in the country, this thesis will also attempt to spotlight the emergence of a new Mozambican feminist cinema supported by new roles played by women filmmakers and the production of cinematic narratives that attempt to construct or represent nuanced subjectivities of Mozambican women.

\section{LITERATURE REVIEW}

The global discourse community \& framing a feminist study of Mozambican HIV/AIDS cinema research.

When Mozambique gained its independence from Portugal in 1975, the Marxist-Leninist aligned political party of FRELIMO (Front for Liberation of Mozambique) had already paid close attention and began harnessing the power of cinema. Following FRELIMO's triumph against the Portuguese, its newfound government led by figurehead Samora Machel, continued mobilizing cinema's postcolonial nationalization possibilities. The revolutionary movement turned government progressively developed a nationalized system of cinema production that has interested many African cinema academics. FRELIMO’s unique approach of recruiting, commissioning and mobilizing filmmakers from clashing communist and anti-communist world 
powers during heightened Cold War and civil rights tensions, its attempts to nationalize cinematic production by training Mozambican visual storytellers during their independence and postcolonial era, the pedagogic, nationalist, political and futurist images produced and the subsequent effects this has had on contemporary national cinema encompasses the focuses of the Mozambican cinema studies discourse community. Moreover, the transforming focuses of this discourse community are inclusive of the current humanitarian crises that face the country and the rapidly globalizing state of film production and consumption in the country.

Even though my focus is on the contemporary wave of HIV/AIDS humanitarian film that emerged in the early 2000's and continues proliferating to this day, academic discourse on the history of national Mozambican cinema is relevant in understanding the canonization of the country's national cinema. Mozambique's anti and post colonial cinematic history begins late into the 1960's and remains a topic largely underexplored in academica. Its discourse community is still loosely defined and has yet to come to a consensus on what constitutes uniquely Mozambican cinematic processes, patterns and phenomena. I will therefore attempt to demonstrate how contemporary academic explorations amalgamate with historical ones as Mozambican national identity is continuously in flux. The process of defining a contemporary national Mozambican cinema is continual and simultaneously conscious of the country's present-day political, social, environmental, economic and pressing health crises, yet rarely separates from its historical systematic and aesthetic origins. I will draw upon academic literature that, while sometimes not specific to cinema, inform the ways humanitarian filmmaking attempts to foster and educate about safer sexual health practices within the national context(s) of 
Mozambique. Moreover, exploring literature that is cognisant of national and sub national specificities of HIV/AIDS epidemiology should reveal important intersections between public health film production/distribution and gender inclusivity, urbanity, rurality and community action. This literature review thus will situate Mozambique's new wave of HIV/AIDS cinemas as a valuable filmic constituent of Mozambican cinema studies through examinations of key multidisciplinary texts and their methodologies.

Perhaps the most notable recent publication on the subject is the all-encompassing book written by Dr. Ros Gray and published in 2020, Cinemas of the Mozambican Revolution. Her book chronologically encapsulates the development of a national Mozambican cinema, focusing especially on the revolutionary, collectivist, pedagogic and nation-building futurist images produced under FRELIMO's leadership. Her book draws on several existing literary works on Mozambican cinema including Mantia Diawara’s “Sonimage in Mozambique” (2003), Marcus Power's "Post-colonial Cinema and the Reconfiguration of Moçambiquinidade" (2004), Guido Convents" "Birth (of the Image) of a Nation: Jean-Luc Godard in Mozambique" (2011) and Ute Fendler's “Cinema in Mozambique: New Tendencies in a Complex Media Landscape” (2014). Dr. Gray successfully compiles a well-researched bibliography with the purpose of presenting what she argues are uniquely Mozambican patterns and processes of production, distribution and spectatorship, ultimately prompting questions on what this national cinema tradition may offer to larger questions of national cinema canons.

Arguably the most important contribution to Mozambican cinema studies that Dr. Gray's book offers is the series of in-person interviews and personal accounts she collects and 
transcribes from her fieldwork in Mozambique, especially those with filmmakers involved in the production of early Mozambican films such as Licinio Azevedo, Dučan Ninkov, Simon Bright, Camilo de Sousa, Chico Carneiro and Sol de Carvalho. Additionally, she offers an extensive filmography in the book, often making her own contextualized visual analyses to support her points. Through her fieldwork and connections to Mozambican filmmakers and producers, Dr. Gray also manages to resurface "lost" films and documentaries, for example, Moira Forjaz and Miguel Arreas' highly criticized Televisão dos Bairros (Television of the Neighborhoods) (1981) which she offers commentary on and deposits to the archive of Cinemateca Portuguesa (Gray 2020, page 203). Besides being an extensive compilation of English, French and Portuguese-language academic sources that comprise the discourse community of Mozambican cinema studies, Dr. Gray manages to bring Mozambican filmmakers themselves into this discourse community by engaging them with academic questions, transcribing interviews and conversations with them as well as making significant contributions to the available filmography of Mozambican cinema.

Historically, the national cinema of Mozambique was developed for pedagogical, sociopolitical and nation-building purposes. Many scholars have been interested in the importance Mozambique placed on cinema production immediately after independence and questioning the influence it had on cultivating a national identity. Marcus Power's 2005 article "Post-colonial cinema and the reconfiguration of Moçambiquinidade" specifically addresses how Mozambican national cinema sought to promote Moçambiquinidade, a Portuguese-language term used to describe a homogenous Mozambican experience, as an identity factor for its 
spectators. Power's article demonstrates academic interest in the Mozambican case study as an example of a successful harnessing of moving image for the purpose of configuring a national identity to a predominantly rural and illiterate audience (Power 2005).

Andrea Meleiro’s six-essay special issue "Luso-African cinema: nation and cinema” published in the 2012 volume of the Journal of African Cinemas compiles works exploring Luso-Afrocan cinema and similarly explores the idea of intertwining nation and cinema and how it has manifested in Lusophone African cinema traditions. Here, the work of Dr. Ros Gray, Maria Loftus and Mahomed Bamba reveal other focuses of the discourse community; international collaboration, militant cinema and development. They describe production patterns of a cinema that comes into fruition during heightened anti-colonial conflict, ambitious yet curbed by limited national funding and as a result, that turned towards international collaborators (cooperantes). Similar production budget hindarences remained following the War of Independence. The construction of a national collectivist, pedagogical and futurist cinema continued relying on international and transnational film collaborators, turning the Mozambican backdrop and its spectators as a sort of experimental ground for filmmakers from abroad to test theorized ideas of a cinema of action (Meleiro 2011; Gray 2012; Loftus 2012; Bamba 2012).

In "Portuguese African Cinema: Historical and Contemporary Perspectives", Claire Andrade-Watkins explores the idea that these patterns of internationally funded production and distribution remain influential in contemporary Mozambican filmmaking. Arguably, these observations can also be applied to the current state of HIV/AIDS cinemas, where international 
and transnational organizations and governments have financial and moral stake in humanitarian film production (Andrade-Watkins 1995).

Mozambique's current dealings with humanitarian crises such as HIV/AIDS has prompted shifts towards a national cinema that deals with these issues. For this reason, scholars engaged in academic fields besides film must be included in this discourse community, given that their work informs the production, distribution and the narrative content of humanitarian cinema. Moreover, epidemiological, sociological and anthropological studies of HIV/AIDS affected populations in Mozambique are similarly interested in understanding the underlying national specificities and applying them to directly affect Mozambican subjectivities. For the International Journal of Culture, Health and Sexuality, Sandra Manuel, a sociologist, describes her research-based findings on perceived obstacles of condom usage among Mozambican urban youth in her paper "Obstacles to condom usage among secondary school students in Maputo city, Mozambique”. By investigating Mozambican manifestations of themes such as love, relationships, extramarital sex and trust, her work reveals discrepancies in public health information roll-out, lack of in-school comprehensive sex education and embeded societal gender disparities that she identifies as contributing factors to the spread of HIV/AIDS (Manuel 2005).

In the published report "Now or Never: Perceived HIV Status and Fertility Intentions in Rural Mozambique.” for the National Institute of Health, Arizona State University scholars of the Studies in Family Planning department Sara R. Hayford, Victor Agadjanian and Luciana Luz place their focus on rural populations. Utilizing population-based surveys from rural 
Mozambique, they draw correlations between societally perceived risks of HIV/AIDS and childbearing potential. Taking a rural population demographic into consideration, their study draws important conclusions that further call for nationwide public health information initiatives and comprehensive sex education that is keenly aware of gender disparities, rurality and misinformation (Hayford et al. 2012).

Victor Agadjanian delves deeper into the causation of social construction of HIV/AIDS risk in Mozambique, evaluating the role of religious organization communications and information campaigns in his two publications: "Talking about the 'Epidemic of the Millennium': Religion, Informal Communication, and HIV/AIDS in Sub-Saharan Africa." and "Religious Organizations and the Fight Against HIV/AIDS in Mozambique." (Agadjanian and Menjívar 2008; Agadjanian 2012). His writing reveals ways religious organizations introduce different, and often contrasting, narratives about HIV/AIDS and sexual relationships. Intersections of all the latter concepts brought forth through multidisciplinary research are evident in the way the non-profit organization Family Health International 360 tackles HIV/AIDS prevention and mitigation on the ground in Mozambique. Entitled "Intergrating Gender and GBV [Gender-Based-Violence] Into HIV Prevention Programming in Mozambique”, FHI360's report demonstrates the successes of program implementation that prioritizes the participation of women in rural and urban communities through information seminars, fostering safe spaces, comprehensive sex education and informative film production and projection (Scranton 2016). By including scholars and professionals of other fields in the discourse community of humanitarian HIV/AIDS Mozambican cinema, it is evident that an intersectional 
and multidisciplinary approach can demonstrate how organizations, activists and governments find value in cinema as a viable tool for transferring beneficial information.

Academic discourse in Portuguese-language scholarship. Academic literature from institutions in Portugal and Brazil have produced scholars interested in Mozambican cinema that offer keen knowledge of postcolonial Lusophone Africa. Portuguese-language instruction prompts scholars in those institutions to turn towards the Lusophone world for research ventures across all disciplines. Mozambique remains intrinsically linked to Portugal because of a prevalent Portuguese diaspora in Mozambique and vice versa, as well as crucial international collaborations that include economic, academic and creative exchange, most notably the established Portuguese Language Countries Community (CPLP, Comunidade dos Países de Língua Portuguesa). The concept of "Lusophony" therefore surpasses the baseline idea of language interchange, but rather represents "an imaginary space of imperial nostalgia so the Portuguese feel less isolated and more visible in the world" (Sousa 2005). Nonetheless, academics hailing from the Lusophone community and diaspora are capable of formulating arguments that prove especially useful for understanding Lusophone postcolonial identities, Mozambican ones in this case.

Portuguese-speaking scholars of Lusophone African cinema bring valuable contemporary perspectives into the discourse community of Mozambican cinema studies. Contemporarily, television and cinema are amongst the strongest bonding agents that foster Lusophony as an identity factor across Lusophone nations. Therefore, academic inquiries into Mozambican 
cinema derived from Portuguese-speaking institutions often see a shift towards contemporary ones. In a paper entitled “The mobilization of the 'Lusophony' concept. The case of RTP International channels", Helena Sousa of the University of Minho in Portugal elucidates the transnational circulation of Portuguese television and movie channels RTP International and RTP Africa (Sousa 2005). Her exploration into the subject demonstrates the contemporary every-day consumer media landscape across the Lusophone world that is still entrenched in Portuguese cinema and television. The RTP conglomeration and its penetrative marketing tactics present Mozambican cinema a challenge of once again reclaiming its national specificity and popularity. Several scholars of Portuguese-speaking countries have therefore found nuanced Mozambicanness in films about HIV/AIDS not only because they are made in the country and without the help of RTP but also because they reveal unique social patterns and norms of Mozambique that surround HIV/AIDS.

Brazilian scholar Esmael Alves de Oliveira has published several articles that focus on humanitarian cinema from Mozambique, specifically pedagogic HIV/AIDS films. His writing calls for a reimagining of "social images" that, despite having humanitarian and pedagogic aims, should be included in discourse of contemporary Mozambican cinema. Fusing cinematic analysis with humanitarianism and development, his writing places special emphasis on the use of the corporeal in representation (de Oliveira; de Oliveira Simone Becker 2018; de Oliveira et al. 2013: Oliveira 2014). From these analyses and reflections, de Oliveira discovers how HIV/AIDS manifests itself in Mozambican society, whether amongst youth, within the family or for women. Amongst those specificites identified are the uptick in pre and extra-marital sex amongst youth, 
prostituion in urban areas and work-related migration of patriarchs to South Africa and back. His methodology is especially relevant to this thesis, as it deconstructs films with uniquely-Mozambican spectatorial processes in mind to derive at ways images work for social action. He reveals how images produced intended to aid the mitigation and prevention of HIV/AIDS must be sensitive to national epidemiological specificities. The Mozambican spectator, according to de Oliveira, is important in all stages of production, from scriptwriting to subsequent distribution.

The methodologies utilized to approach films and documentaries will prove productive to this thesis' framing of HIV/AIDS humanitarian cinema as a valuable new wave of Mozambican cinema and leaves room for a particularly feminist inquiry into them. Identifying a discourse community of contemporary Mozambican cinema studies reveals the need to approach it with intersectional and multidisciplinary approaches. HIV/AIDS cinemas in particular are products of a nuanced pre-production epidemiological understanding of the virus and the nationally-specific societal norms that surround it such as differences in urbanity and rurality, cross-border migration, Portuguese neocolonial influence, comprehensive sex educuation roll-out and gender disparities. Despite its historical attempts to nationalize a film industry as an anti-colonial and independence project, modern Mozambican audiences are less familiar with politically-oriented pedagogic films. Film studies of Mozambican national cinema instead point towards its contemporary entrapment in foreign markets, especially that of Portugal and a decline of local productions. HIV/AIDS cinemas therefore appreciate the specific nature of the Mozambican spectator, crafting narratives familiar in form to the new generation of Mozambican audiences. 
The pedagogical purpose of HIV/AIDS cinema is not lost as humanitarian organizations and government-funded sex education initiatives have turned towards engaging narratives and film screenings as part of their HIV/AIDS mitigation and prevention strategies. These efforts point towards an especially important need to amplify Mozambican women's subjectivities in these films given that women are disproportionately affected by HIV/AIDS in negative economic, social, educational and epidemiological terms. Mozambican national cinema, in this wave of HIV/AIDS films, is therefore approaching a new intersection with feminist ideology that seeks to portray nuanced cinematic representations of Mozambican women like never before. Women play a significant role in these productions, whether it is in pre-production understanding of the gendered epidemiological HIV/AIDS crisis, the inclusion of women and feminist filmmakers and actors during production or in narratives that center on Mozambican women. Women play important roles during distribution endeavours as well, aim to reach, educate and inspire Mozambican women to make individualized empowered stances against gender based violence and HIV/AIDS. My inquiry into the current state of contemporary Mozambican cinema will propose an analysis of HIV/AIDS films that is intersectional, multidisciplinary and especially feminist in its approach.

TOWARDS A THEORETICAL FRAMEWORK OF AUTHENTIC MOZAMBICAN CINEMA INCLUSIVE OF HIV/AIDS HUMANITARIAN CINEMAS

Out of all global cinema traditions, the question of authenticity seems to be especially tied to inquiries into postcolonial African film. Sub Saharan African nations in particular were 
amongst the last to see an emergence of cinema traditions not dictated by colonial oppressors. Financial, technological, distribution and staffing limitations for film production in the area set the stage for a much less abundant cinema in comparison to the booming industries in Europe, the United States and Asia. In the case of Mozambican cinema, films that exist and have been distributed on an international scale are complicated by the question of self-representation. Especially before the advent of digital technologies, long-form conventional narrative filmmaking "worth" international distribution required at least some level of filmic training, a budget that allows a vision to come into fruition by paying cast and crew, and access to distribution channels (film festivals, cinematic releases, streaming platforms, etc.). All of the latter privileges of conventional filmmaking are disproportionately available to the West, and in non-Western countries, to non-indigenous populations. This scarcity of large-scale self-produced representations of indigenous subjectivities calls for a film scholarship that constantly questions even the most well-intentioned cinematic depictions of Mozambican subjectivities. This section will seek out a possible theoretical framework for inquiries into Mozambican national cinema that contextualize its historical development, outline contemporary systems of production and question its attempts to authentically amplify Mozambican women's subjectivities as part of the new wave of HIV/AIDS humanitarian cinemas.

The golden age of national Mozambican cinema, post-independence and the onset of the HIV/AIDS epidemic. The Frente de Libertação de Moçambique (FRELIMO) began its anti-colonial operations in 1962, while Portugal's authoritarian control of the country remained strong. Because FRELIMO was deemed a terrorist guerilla by the Portuguese government, it was 
originally headquartered in Dar Es Salaam, Tanzania. There, FRELIMO hosted Mozambican refugees fleeing colonial oppression and set up military training, schools and settlements to advance their armed struggle. FRELIMO guerillas eventually penetrated the Mozambican border in an armed insurrection beginning in 1964, marking the beginning of liberation. The northern areas of Nachingwea and Cabo Delgado, where FRELIMO successfully banished Portuguese authorities became known as "liberated zones" and was where filmmakers, journalists and photographers were invited from abroad to cover the armed struggle (Gray 2020, page 15-17; Gray 2013). Revolution in Mozambique became synonymous with FRELIMO's armed struggle, especially for filmmakers, many of whom visited Mozambique from abroad on FRELIMO's invitation. Yugoslavian, Chinese, Soviet, European and American filmmakers alike produced films that emphasized the necessity of FRELIMO's armed struggle. Internationalist representations of the armed struggle were important to FRELIMO, mobilizing filmmakers from China (Yuben Wang, The People of Mozambique are Fighting On, 1970), producing a film highlighting agricultural and medial collectivism, Yugoslavia (Dragutin Popovic, Venceremos, 1968), documenting the triumphs of armed struggle and independence, the USSR (Leonid Maksimov, Viva Frelimo!, 1971), privileging the image of Samora Machel, Sweden (Ingela Romare, Mozambique is Our Country, 1967) reporting on atrocities to Swedish audiences and the United States (Robert van Lierop, A Luta Continua. 1972) shedding light on revolution as a social process of transformation and aligning itself with US Civil Rights activism (Gray 2020, page 32). Regarding the invitation of foreigners into liberated FRELIMO zones, Dr. Ros Gray points out that "this geographical range indicates the plural approach that Frelimo took during 
the armed struggle in cultivating alliances across the divisions of the Cold-War and the Sino-Soviet split" (Gray 2020, page 15). Coverage of atrocities committed by the Portuguese in Mozambique, such as the Wiriyamu massacre that left 385 civilians dead, contributed to the dismantling of the Portuguese empire's image internationally, which they had been able to control previously through censorship. Additionally, domestic uprisings across Portugal itself and condemnations from crucial allies that called for the end of the oppressive regime within POrtugal led to the relatively peaceful domestic Portuguese uprising, dubbed the "Carnation Revolution", bringing and end to the New State ${ }^{1}$ in 1974. Subsequently, Luso-African political parties such as FRELIMO, who were once denounced as terrorist organizations were faced with the possibility of bidding for independence. On June 25th, 1975, in Lourenço Marques (now Maputo), Portuguese flags were lowered and the new Mozambican flag was hoisted in a ceremony led by Samora Machel, Mozambique's first President.

Upon being granted independence as a sovereign state, FRELIMO, the Marxist-Leninist armed resistance party of Eduardo Mondlane and Samora Machel fell into the immense task of unifying an ethnically diverse, multi-lingual and fragmented population with a homogenized vision of the nation, an effort it had already begun during its armed struggle with cinema as a primary pedagogical tool. Mozambique is a large country, home to a multitude of ethnic groups including the Tsonga, Macua, Swahili, Chopi, Sena and Maviha peoples, all of whom have different languages and religious practices. Regardless of their diversity, the Mozambican people shared 500 years of Portuguese colonial rule and the imposition of Portuguese values onto

\footnotetext{
${ }^{1}$ The Estado Novo (New State) is the title given to the authoritarian Portuguese regime that lasted from 1933 until its dissolution in the 1974 coup d'etat (see Gallagher 1979: Alexandre 1993)
} 
society. FRELIMO was determined to "create a new society based on egalitarianism and communalism and to bring about national integration and development" (El-Khawas 1980, page 24). Cinema production, which had been at the forefront of Frelimo's transnational collaboration and raising of awareness towards their revolutionary cause now becomes a valued pedagogical tool for the Mozambican masses.

Films produced during the armed struggle were not screened in the country, but rather were projected abroad for foreign sympathizers. Immediately upon independence in 1975, FRELIMO began showing pro-revolution socialist films such as The People of Mozambique are Fighting On (1971), From the Rovuma to Maputo (1972) and Viva Frelimo! (1971) to Mozambican audiences first as part of independence celebrations and later, in urban and rural areas throughout the country utilizing a system of mobile cinemas units. Donated by the Soviet Union, the cinema móvel units were not a novelty in Mozambique. Marcus Powers describes the use of a similar cinema ambulante by Portuguese advertisers used to project films that worked to promote consumer goods to indigenous Mozambicans (Power 2005, page 268; Gray 2014, page 10: Gray 2020, page 7-18, 109, 153, 169). FRELIMO noticed the successful audience attendance at these recycled films of the revolution and recognized the possibilities of this system of distribution for empowerment and pedagogy. This in turn prompted a shift in production towards films that were focused on health, agriculture and development, yet still upheld the socialist values of the party.

The First National Conference, which was held in November 1975, included discussions about the possibilities of a national cinema. A plan was devised by Jorge Rebelo, Mozambique's 
first Minister of Information, to mobilize Mozambican cinephiles, filmmakers and intellectuals to form a nationalized institute of Mozambican cinema. Americo Soares, Luís Carlos Patraquim, Mota Lopes, Maria de Lourdes Torcato, Julius Kazembe and Luís Simão became the founding members of the Instituto Nacional do Cinema (INC), which inaugurated in March of 1976, only one year after Mozambique's independence (Gray 2020, page 109). In conversation with Maria de Lourdes Torcato and Luis Simão, Dr Ros Gray concludes INC’s mission:

"to invent a revolutionary nationalist cinema for Mozambique, one that would reflect Mozambican realities and that would promote national unity through films in Portuguese. For the first time, the technology of film would make a universal address to all Mozambicans, uniting the people from the Rovuma to Maputo" (Gray 2020, page $\underline{111)}$.

The newfound Mozambican government of FRELIMO became the only liberated African nation to found a nationalized film institute almost immediately upon its independence, making cinema a crucial tool for the nation-building process. Mozambique's experiment with a national revolutionary cinema represented a crossroad of transnational experimental cinema for social action, and resulted in an arguably uniquely Mozambican cinema.

The development of the INC was inspired by Cuba's Film Institute (ICAIC), whose origins were derived from the Latin American film tradition of Third Cinema, first coined by Argentine filmmakers Fernando Solanas and Octavio Gettino. They called for liberated societies in Latin America, Asia and Africa to reject the modalities and conventions of American Hollywood and European art cinema and identified a necessity for a "third" cinema, where 
filmmakers become part of a collective nationalist or political movement and whose productions were not rooted in escapism but rather, in action (Solanas and Getino 1970; Stam 2004). Third Cinema's conceptualization was inspired by the Afro-liberation movements of Frantz Fanon and Amilcar Cabral, a Lusoafrican nationalist political figure from Guinea-Bissau, and thus, a Mozambican adoption of this cinematic model was based on exchanges with Latin American and Lusophone African revolutionaries (Stollery and Lev 2001). For Samora Machel and FRELIMO, the Third Cinema model offered the possibility of a highly influential form of cinema, prompting Cuban filmmakers from the ICAIC to be invited to Mozambique to train Mozambican filmmakers for the INC (Pasley 2009, page 109-111). Simultaneously, ideas of the Brazilian tradition of cinema novo were brought to Mozambique by Mozambican-born Brazilian-Portuguese Ruy Guerra, a prominent director in the movement. With a principally participatory nature, Cinema Novo had sought to emphasize intellectualism and social inequalities during years of divide in Brazil and drew its inspiration from European traditions such as Italian Neorealism and the French New Wave (del Sarto 2005). Mozambique's lack of professional actors and studio-quality film equipment combined with the governmental pressure of producing films that inspired anti-colonial and nationalist sentiment that aimed to generate intellectual spectatorial response from audiences prompted Guerra to return to his country of origin and apply the methods of Brazilian Cinema Novo. In 1979, Guerra directed Mueda, Memória e Massacre (Mueda, Memory and Massacre), a film that depicted the 1960 Portuguese colonial army's massacre of six hundred civilians in the town of Mueda (Ukadike 1994, page 239). Regarded as the first fiction film from Mozambique, the production utilized 
non-professional Makonde actors from the affected village of Mueda who reenacted the massacre in traditional Makonde theatricality, an event that occurred yearly and had not been captured on film. Ruy Guerra's Mozambican experiment with Cinema Novo privileged regional Makonde traditions of theater and constructed the country's first non-documentary film not intrinsically rooted in pedagogy or socialist propaganda. Regardless, it simultaneously offered a nationally-relevant nostalgic recalling of traumatic memory and anti-colonial revolution that benefited the nation-building aims of socialist FRELIMO's INC.

The emergence of a Mozambican cinematic tradition also relied on significant European exchange, which notably included the government's invitation of Jean-Luc Godard of the French New Wave tradition and Jean Rouch, a pioneer of Cinema Verité. Arriving in 1978 with video equipment and a team of filmmakers, Godard wanted to introduce TV to Mozambique, "challenge conventional TV formula", "examine the impact of sound and images on people" and "(he) wanted the viewer to participate in the making of images rather than just being a passive recipient of images and their messages" (Pasley 2009, page 118). Jean Rouch was invited by the Mozambican government to the University of Maputo in order to introduce Super 8 technology with hopes of using its portability to produce pedagogical films to advance a budding literacy campaign and health education. According to Victoria Pasley and Manthia Diawara, Rouch was heavily criticized for the proposed Super 8 project by African filmmakers who preferred $16 \mathrm{~mm}$ and $35 \mathrm{~mm}$ film, including Ruy Guerra who saw the use of Super 8 and the methods of cinema verité as "too simple minded and detrimental to mise-en-scene" (Pasley 2009, page 117). Additionally, Rouch was allegedly accused of "neo-colonialism and wanting to keep Africa 
technologically underdeveloped” (Pasley 2009, page 117; Andrade-Watkins 1995, page

186-187). Both Godard and Rouch were staunch defenders of their filmmaking methodologies, leading to a clash between a government that strictly sought cinema's nation-building possibilities and two filmmakers who saw Mozambique's cinema landscape as fertile experimental ground for their ideas, ultimately resulting in both projects never being fully implemented. Despite the projects not coming into fruition, Rouch and Godard's invitation and ultimate retraction from filmmaking projects in Mozambique demonstrates the transnational exchange crucial to the development of Mozambique's national cinema, the extent of autonomy the INC and Mozambican filmmakers had in decisions of film production and FRELIMO's goal of producing images that specifically addressed the Mozambican people (Pasley 2009, page 116-119).

The mobile cinema tradition in the country continued with the INC and the help of newly trained Mozambican filmmakers. Likely the most notable productions that took advantage of this far-reaching distribution system were the educational and nationalist docu-drama newsreels, Kuxa Kanema. The series of approximately “395 weekly editions, 119 short documentaries and 13 long documentaries or features" were screened across the country with mobile cinema units and covered a range of pedagogical and nationalist themes such as health, armed struggle, regional destabilization, agriculture, Portuguese language, national pride and cultural exchange (Pasley 2009, page 119). The production of the Kuxa Kanema films represents the birth of an organized national cinema that emphasized the advancement of nationalist, revolutionary and socialist sentiments in the country through film and transnational collaboration. The era in which 
Mozambican cinema reached its golden age of production must be considered as a crucial context to its development. Liberation movements across Africa, the Black Power movement in the United States, the Sino-Soviet split, the Cold War and Marxism-Leninism's global escalation were background conflicts and dilemmas that influenced FRELIMO's experiment with cinema. Filmmakers were invited to Mozambique from around the world with distinct ideas, theories and methods of what a revolutionary cinema of social action would look like and applied them to their collaborations and their training of Mozambican filmmakers. The INC drew inspiration from transnational collaborations and maintained allegiance to FRELIMO's vision of nation-building, resulting in a national revolutionary cinema that was uniquely of Mozambique and for Mozambicans.

Through the 1970's and 80's, Mozambican cinema flourished under the INC and the continued foreign collaborations with visionaries of revolutionary cinema. Besides the continuing of the Kuxa Kanema pedagogic films, narrative productions became more prevalent and offered nostalgic narratives of Mozambican subjectivities. The INC's first feature film was the Yugoslav-Mozambican co-production O Tempo dos Leopardos, 1985 (The Time of the Leopards) directed by Zdravko Velimirović. Set in Mozambique in 1971, O Tempo dos Leopardos fictionalized the end of Portuguese colonial occupation in Mozambique, allowing the colonised to retell the story of their liberation. That same year, Mozambican director José Cardoso's O Vento Sopra do Norte, 1985 (The Wind Blows from the Night) offered a fictional account of young Mozambican romance juxtaposed with the tense anti-colonial guerilla warfare of the 1960's. O Vento Sopra do Norte was directed and staffed by Mozambicans and included an 
all-Mozambican cast, demonstrating the growing technical capacity of the INC and their ability to create self-representations that foster a shared national identity.

Virtually all films and documentaries produced during these years and under the Kuxa Kanema mission explored memories of the War of Independence or took a nationalist, collectivist pedagogic stance. The "nation" was at the forefront of these productions, which attempted to paint an image of a unified postcolonial society. Nevertheless, it is important to note that films produced under the INC such as O Vento Sopra do Norte and O Tempo dos Leopardos featured mostly male heroes and their supportive, albeit participant wives and daughters (Gray 2020, page 241). The Marxist-Leninist filmmaking of FRELIMO was concerned with aiding the construction of a homogenized Mozambican identity that was based in inherently patriarchal anti-colonial, revolutionary sentiments.

Despite attempts to depict women as equal participants in the revolutionary fight against colonial oppression, the movement's preoccupation with unity seemingly failed to address a simultaneous growing gender disparity. In José Celso and Celso Luccas’ 25 (1975) and Margaret Dickinson's Behind The Lines (1971), women are depicted as necessary, equal, gun-wielding participants in the armed struggle against the Portuguese. In attempts to promote FRELIMO's feminist stance, other films privilege the heroic posthumous image of Josina Machel, Samora Machel's late wife who died at the age of 25 before Mozambique's independence. In American Civil-Rights filmmaker Robert Van Lierop's A Luta Continua (1973), a close-up of a nursery named after Josina Machel serves to “assert Frelimo's aims at changing patterns of life” by showing a newly-founded Mozambican "institution that was only available for the rich under 
colonialism" (Gray 2020, page 55). A more explicit call for an active societal emancipation of women comes in French-backed Etudier, Produire, Combattre (1973), where FRELIMO's decolonial pedagogy is explained as deliberately taught anti-colonial approaches to formal education, agricultural production and armed struggle. While students are sitting in on a classroom, a close-up of a notebook decorated with an image of Josina Machel is accompanied by a voice over exclaiming that "students also need to transform their relationships with one another and work towards the emancipation of women" (Gray 2020, page 62). This demonstration of FRELIMO's decolonial pedagogy offers no explicit deliberation on what and why gendered disparities exist, but instead works to display the theorized idea of "New Man", a model of a new revolutionary subjectivity that defines a specifically "Mozambican personality" (Gray 2020, page 63). Dr. Gray explains this devised subjectivity as FRELIMO's project to introduce how "new ideas and comportments would form the basis of social relations to replace those that existed under the colonial system" which included "aspects of 'traditional' Mozambican society, which Frelimo saw as being mired in exploitation, corruption, sexism, racism, obscurantism, tribalism and alienation from African roots" (Gray 2020, page 63).

FRELIMO's contestation between a newly conceived Mozambican subjectivity based on Marxism-Leninism and simultaneous attempts to promulgate pre-colonial traditionality resulted in a rather confusing approach to Mozambican women's subjectivities on screen. A Kuxa Kanema episode portraying the first National Festival of Dance follows three young women during the rehearsal and performance of a masked Makonde song and dance. In his paper entitled “Feminist Masquerades and Women's Liberation, Nangade, Mueda, Muidumbe, 1950s-2005", 
Paolo Israel describes how "a group of Makonde women guerillas invented a flamboyant feminist mapiko mask, venturing in a terrain traditionally reserved for men" and how "the invention spread throughout the plateau, becoming the signature dance of a generation of women empowered by the revolution" (Israel 2013, page 1-4). This portrayal of Mozambican femininity is tied to revolution and resistance, therefore, it represented the perfect subject matter for a Kuxa Kanema episode because it showed how the post-colony sought to challenge colonial anthropological inquiries of indigenous dance and song by offering new prideful nationalist sentiments of traditionality to Mozambican audiences. Israel demonstrates how it is possible to interpret Makonde song-and-dance as a truly feminist display of women's expression and affect in regards to revolution, armed struggle and post-colony independence. Nonetheless, the way it is appropriated cinematically by the INC as a Kuxa Kanema reel perpetuates how, through a carefully audited narrative meant to foster nationalism, "the participation of women in the anti-colonial guerilla war through which Mozambique achieved Independence has the status of a myth within the great myth of Frelimo's Armed Struggle for National Liberation” (Israel 2013). Despite the privileging of images of revolutionary women throughout the history of Mozambique's National Institute of Cinema, paying close attention to their use reveals the lack of nuanced women's subjectivities present in early national Mozambican cinema.

The INC and national cinema production began to deteriorate during the late 1980's and early 1990's because of a series of growing domestic political and humanitarian crises afflicting Mozambique. Anti-communist sentiment was proliferating, giving a rise to The Mozambican National Resistance (RENAMO) and the Civil War against FRELIMO occupation. In 1986, the 
abrupt and mysterious death of Samora Machel marked the end of Mozambican socialism and the height of the Civil War, and soon after his death, FRELIMO underwent an internal crisis, during which the Soviet Union ceased their crucial funding of the INC. Additionally, in late August of 1991, the headquarters of the INC in the capital city of Maputo suffered a devastating electrical fire that resulted in the loss of thousands of film archives and ongoing cinematic productions, including the majority of Kuxa Kanema newsreels. The devastation of the Mozambican Civil War and the fire at the INC left all Mozambican filmmakers unemployed, signifying the end of Mozambique's experiment with a state-run national cinema and a shift to film production based in a privatized market (Gray 2020, page 264).

Contextualizing HIVIAIDS gender disparity. Mozambique's epidemiological gender disparity intersections began with the patriarchal structures left by 400 years of Portuguese colonialism, where women were relegated to secondary societal roles and forced labour. This prompted permanent disturbances to the established social orders of the Makonde, Tsonga, Makua, Chopi, Ndau, Yao, Swahili, Gaza, Maviha, Sena, Ndwandwe, Lemba and Shona peoples, all of which resided and were subsequently fragmented within the borders of Mozambique. Contemporarily, the imposition and dominance of "patriarchal universalistic religions, especially Catholicism" continues to disrupt traditionally observed gender roles and conceptualizations (Israel 2013, page 203). The nationalization of the Portuguese language also separated Mozambique from its English-speaking neighbours and gradually cemented patriarchal systems into institutions (including schools and universities) and familial structures. Moreover, new exposure to 
international media and globalization is progressively transforming the social fabric of Mozambique, most importantly for this case, the extra and pre-marital sexual practices amongst teenaged youth and young adults (Karlyn 2005, page 280). As HIV/AIDS became a more pressing issue in the country, ex-INC filmmakers began receiving funding from transnational humanitarian organizations for film productions that aimed to to help the mitigation and prevention of HIV/AIDS by addressing Mozambican audiences about the crisis pedagogically. On one end, this signaled a new wave of Mozambican cinema. On the other hand, filmmakers were restricted by humanitarian frameworks and an allegiance to the agendas of the organizations that employed them. Tackling the epidemiological crisis of HIV/AIDS with nuanced cinematic self-representations that appeal to predominantly Mozambican audiences is to simultaneously tackle some or all of the aforementioned intersected issues.

\section{HIV/AIDS CINEMA IS NATIONAL MOZAMBICAN CINEMA}

Cinema has been used as a crucial medium to inform the public on the risks related to HIV/AIDS since it was first discovered in the 1980's. In the United States, films such as John Erman's An Early Frost (1985) and Jonathan Demme's Philadelphia (1993) were pivotal for changing the American public's perception of seropositive people. As HIV infections became more prevalent in other parts of the world, filmmakers instead turned towards the national contexts from where they work. Mozambican filmmakers are attempting a similar feat with HIV/AIDS films, adapting their cinematic depictions of seropositive people so that they speak specifically to the way Mozambicans interact with and understand HIV/AIDS today. An 
important direction these filmmakers must take for their films to be successful in Mozambique is basing their narratives on the specific challenges the country faces against the spread and containment of HIV/AIDS. This requires a nuanced understanding of the different perspectives towards the virus and the audience they seek to address. Perhaps the most important pre-production consideration is the difference between public perceptions about HIV/AIDS in Western countries and the rest of the world.

Contemporarily, personal prevention methods, availability of antiretroviral medication, lifelong implications and debunked stigmas about people living with HIV are more understood in the Western world, where transmission rates have fallen drastically since the onset of the disease. Gendered distribution of HIV/AIDS is still vastly different in Western countries, where homosexual men are most at risk, than in the Global South, where young women and children are the most vulnerable populations. Therefore, filmic communications of reaching parameters of HIV/AIDS prevention "successes" in the Global South do not translate to those relevant and resonant to Western audiences. This has caused a new phenomenon known as "donor fatigue", that has seen dropping rates of Western individual-donor funds to aid organizations that tackle HIV/AIDS in Sub Saharan Africa. (Moszynski 2010). The purpose of cinematic representations of the HIV/AIDS crisis in Sub Saharan Africa has therefore shifted away from aiming to appeal to Western audiences. Instead, pedagogical and empowerment narrative models towards HIV/AIDS cinema have been developed to promote introspective and communal reflections in domestic audiences for prevention and mitigation purposes. Critically approaching the gendered disparities in prevalence rates through cinematic interventions even within the "AIDS belt" must 
reject homogenized explanations to the international phenomenon. Instead, attentiveness towards specificities in domestic structures of Southern African nation-states must be taken into account. In Mozambique, the need to address the HIV/AIDS crisis domestically has resulted in the re-emergence of INC-era aims of achieving a uniquely Mozambican image through a cinema of action. This time around, instead of fostering nationalist sentiments to upheave a political ideology, filmmakers are attempting to craft narratives that are true to contemporary Mozambicans dealing with the threats of HIV/AIDS and that hope to inspire action towards its mitigation and against its spread. Instead of a political ideology, these films are intended to educate about viral transmission, encourage daily antiretroviral therapy and inspire women's agency. Arguably, the level of authenticity represented by this new wave of social action films is an especially relevant question needed to be asked not only by academics that review them but by the filmmakers themselves who seek to offer images of the current state of Mozambique to Mozambicans. No longer bound to a nationalized institute of cinema, filmmakers are faced with more creative freedom in visually exploring HIV/AIDS. There are no inherent political nor nation-building goals but rather humanitarian and pedagogical ones.

Today, filmmakers producing HIV/AIDS cinema are working under similar contexts than during the national identity building origins of National Mozambican Cinema under FRELIMO leadership. A notable parallel between then and now is the transnational flow of funding for these productions. During the time of the INC, friendships with foreign governments proved crucial to the successful production and distribution of national Mozambican films, which included the funding and donations of mobile cinema units from the Soviet Union, studio 
equipment from Yugoslavia as well as filmmaker delegations from Britain, the United States and Sweden. These transnational collaborations benefited the development of Mozambique's national cinema and helped the strengthening of diplomatic ties. Simultaneously, the Cold War backdrop to these collaborations meant that the countries involved had a stake in Mozambique's adoption of communist-inclined political ideologies. Post-Cold War international agreements between foreign governments, organizations and Mozambique are instead rooted in humanitarianism, public health and development. Governments and non-profit organizations now fund Mozambique in order to maintain diplomatic ties and to have a stake in the country's development. HIV/AIDS in particular represents a transnational epidemiological crisis that affects all countries, and Mozambique remains one of the most heavily affected countries in the world. For this reason, funding for HIV/AIDS cinema derives from humanitarian projects that understand the need to approach the crisis with domestic interventions, therefore, humanitarian films are still seldomly produced fully locally.

Even though foreign governments and transnational non-profit organizations are the primary funders of HIV/AIDS cinema, the principal goal of producing films that address the crisis is to explicitly target Mozambican audiences. Mozambican filmmakers, many who once worked for the INC, are often given creative control over their projects because of their ability to capture nuanced Mozambican subjectivities. Some filmmakers that were once employed with the INC and have now found themselves working on HIV/AIDS films include Licínio Azavedo (Historias communitarias, 2002), Gabriel Mondlane (A História de um Mineiro, 2001) and Sol de Carvalho (O Jardim do Outro Homem, 2007). Their former training inspires films that not 
only deal with the epidemiology of HIV/AIDS, but also to the social issues that intersect with its spread, such as cross-border migration, patriarchal institutions, sexual violence against women, prostitution and familial stigmas.

Distribution methods from this new wave of HIV/AIDS humanitarian cinema also parallel those utilized during the development of a national cinema. FRELIMO had employed the use of mobile cinemas to target rural populations and screened their films in public festivals and community centers. Similarly, nonprofits today have adopted similar tactics of distribution to reach Mozambican audiences, projecting films with travelling cinemas, in dedicated community centers and in city theaters. Family Health International (FHI 360) is one example, whose field methodology is approaching local community-led Mozambican HIV/AIDS organizations with resource and training opportunities. A primary focus of FHI 360's field work in recent years has been "Integrating Gender and Gender Based Violence Into HIV Prevention Programing”. Dedicated safe spaces for women and their children have been opened across the country, where events, discussions and community sessions are held. For the purpose of these community sessions by Capable Partners Program (CAP), a partnered NGO produced and distributed "four high quality, provocative short films designed to complement the curricula. The films portrayed relevant local situations highlighting barriers to adoption of safe sexual practices — spurring discussion and learning". (Scranton 2016, page 3). Training of community volunteers for the CAP program is facilitated by pedagogical filmmaking as well. Volunteer work training must also account for low Portuguese literacy rates in rural and outskirt urban areas and a simultaneous eagerness of youth to get involved. 
Italian NGO "Cinema Movel" has adopted the mobile cinema distribution practice of early rural Mozambican film distribution. Their organization has mobile cinema initiatives around the world that aim to iterate communication of an equitable society and rights to sanitation. Their Mozambican initiative screened entertainment films, as well as pedagogic films on safe sex practices, an innitiative that recevied praise from Mozambican women's rights activist Graca Machel Mandela (Graça Machel). Mobile cinemas are very well received in rural areas of Mozambique, where communal cinema exhibitions are scarce. Cinema Movel's model of film distribution demonstrates the intrinsic value in spectatorial spaces that include all members of a community. Moreover, their successful mobile cinema approach sheds light on the continuing need to reach rural Mozambican audiences with unconventional film distribution methods.

Social Transformation and Empowerment Projects (STEPS), a South Africa-based NGO, has a project dedicated solely for the participatory production, and domestic distribution of films about public health, refugeehood and women's human rights across four countries in Southern Africa, including Mozambique. With its "Steps for the Future" project, STEPS uses a multi platform distribution approach, from facilitated community screenings, broadcast television programs and public service announcements via its social media outlets. STEPS is a unique organisation because its sole focus is the production and pedagogical distribution of humanitarian African cinema. Originating in 2001, it is "part of an international AIDS awareness project initiated by IKKA Vehkalahti/Finnish Broadcasting Corporation and funded by YLE Finland, BBC, UNAIDS, TV2 Denmark, SVT from Sweden, RTBF from Belgium, SABC, the 
European documentary Network, Dominant 7 from France, Treatment Action Campaign, the Embassy of Finland, SAFAIDS and the Soros Documentary Fund" (Joffe and Jacklin 2003. figure 3.4). STEPS is directed by South Africans and, unlike previously mentioned American and European NGOs, its transnational pool of funding represents a cooperation between humanitarian entities, philanthropic organisations, foreign governments and cinema funds while its management and implementation are African. Its regional focus has facilitated prioritized collaboration with local film production companies and informative film screenings. Ebano Multimedia, Iris Imaginações and Cool, three of the five independent film production companies in Mozambique have produced films for the "Steps into the Future" project (Joffe and Jacklin 2003, page 14-15). By allowing Mozambican filmmakers creative freedom, allocating significant funding for their productions and guaranteeing them a pedagogical distribution platform, films produced for this project have enabled diverse cinematic representations of Mozambicans living with HIV that extend beyond the virus' sexual implications. For example, Dancing on the Edge (Karen Boswall, 2001) tackles the contradictions between traditional Mozambican gender roles and modernity, rurality and urbanity by following a city AIDS nurse on a journey to a rural village where she takes part in a young girl's initiation ceremony into womanhood. Night Stop (Licínio Azevedo, 2002) depicts the devastating causes and consequences of sex work along a popular long-distance trucking route. For younger audiences aged 5 to 8 years old, the True Friends trilogy (Bert Sonnenschein, 2002) tells three stories of HIV/AIDS with animal-themed hand puppets; The Razor Blade demonstrates the ease of AIDS treatment and confronts the fear of medical doctors by relating their practice to traditional healers, Little Soldiers explains the 
virology of AIDS with a simplified explanation of white blood cells and malignant viruses, and True Friends challenges the ostracization of seropositive with a heartwarming story of accepting friends. A Miner's Tale (Nic Hofmeyr and Gabriel Mondlane, 2001) “addresses poverty, the exploitation of migrant labor, contradictory social expectations between cultures, and how to incorporate biomedical information with traditional forms of knowledge" (McGuffie 2018, page 144). Facilitators of Steps for the Future who show audiences $A$ Miner's Tale are provided with the following post-screening discussion questions to reflective and educational conversations between HIV experts and audiences:

What is the film about?

Why does Joaquim want to tell his wife, Rosita, in Mozambique that he is HIV positive? Why did he want to use condoms with her?

Why did Joaquim's Elder not want him to use condoms with his wife in Mozambique?

What would Rosita think if her husband used condoms when having sex with her? What are the problems migrant labourers and their families face?

What is the connection between migrant labour and the spread of HIV?

Which of the characters do you sympathise with and why? (RayRay-Ntsane and Chislet 2007; (STEPS For The Future : 2013)

By using documentaries and short films, STEPS" "Steps for the Future" project demonstrates success in empowerment and pedagogy through attentiveness in local cinema traditions, extensively enabling the filmmaking process, employing a comprehensive distribution model and 
by fostering interactive spectatorship. Its films find their place in contemporary Mozambican cinema because they exemplify a nuanced cinematic dissection of societal issues that intersect with HIV/AIDS without dwelling solely on epidemiological mitigation and prevention methods.

The Mozambican government has also sought ways to implement screenings of HIV/AIDS films into public school curriculums. The Mozambican National Council for the Fight Against HIV/AIDS, funded by the Ministry of Health implemented film screenings and classroom discussions at part of their curriculum of comprehensive sexual education (CONSELHO NACIONAL DE COMBATE AO HIV/S..., page 15). The screenings are followed by audience response as group discussions and occasional homework assignments. A pedagogical guide with discussion questions is provided to the educators who facilitate the screenings and discussion. A combination of narrative and documentary films such as Sol de Carvalho's Another Man's Garden, Gabriel Mondlane’s Silenco da Mulher (2008) [Silence of the Woman], Karen Boswell's Dancing on the Edge (2008) and Licinto Azavedo's Nightstop (2002) are screened, covering thematic intersections of HIV/AIDS and personal relationships, family, motherhood, sex work, rurality, urbanity, patriarchy, testing and medical interventions. These films rarely leave Mozambique, a notable exception being O Jardim do Outro Homem (Another Man's Garden) (2007), which has been picked up by streaming giant Amazon Prime and is available to stream all over the world (see analysis of the film on pages 43-47). The film also belonged to a box-set of distinct African films, and in this case, did stand as representative for Mozambique. The box-set included films from South Africa, Ghana, Ivory Coast and 
Mozambique, each of which touched on a social dilemma in their respective countries. The Global Lens Collection is an initiative by the nonprofit organization Global Film Initiative, who seek to foster cross-cultural understanding by distributing films from developing countries to university and high school classrooms in the developed world. The inclusion of Sol de Carvalho's film in this box-set reveals the possible dimensions of HIV/AIDS cinemas from countries such as Mozambique. Despite it being a principally pedagogical film for Mozambican audiences, when a film that depicts the intricacies and intersections of youth and HIV/AIDS travels abroad, it can help a more nuanced understanding of social issues often depicted one-dimensionally.

In conversation with Buala, a Portuguese-language digital archive for Lusophone postcolonial cinema, art and academic papers, pioneering Mozambican filmmaker Sol de Carvalho asserts the provocative and pedagogic stance of his filmmaking and simultaneously highlights the duty of producing a certain type of cinema that aims to please the agenda of international humanitarian funding (Pereira 2011). Swissinfo.ch, a prominent news source that often highlights foreign humanitarian Swiss involvement, describes the commerciality of the film in the domestic Mozambican cine-space, saying it "claim(ed) a budding return of Mozambican cinema to its theaters" (Rolletta 2007). In the interview, de Carvalho identifies commerciality in the capital city as the first step of distribution and describes ongoing initiatives to tour rural and underprivileged urban areas in Mozambique to screen the films to as many Mozambicans as possible. Most importantly for him are his correspondences with the Ministry of Education. 
Despite its commercial success with projections in the capital city, the ultimate goal is to distribute this film in classrooms across the country (Rolletta, 2007).

Not only should HIV/AIDS cinema be considered National Mozambican Cinema and given proper filmic attention, I would argue they are even more "revolutionary". First, there is the case of more Mozambican filmmakers trained with expertise in film production, which means less foreign involvement in narrativizing Mozambican subjectivities. Second, we may accept that the HIV/AIDS epidemic is just a different crisis context under which Mozambican films are produced, as opposed to the anti-colonial armed struggle and subsequent Civil War crisis from which national Mozambican Cinema found its origins. The epidemiological crisis has now in essence, forced the narrativization of women's subjectivities not just in regards to the spread of HIV/AIDS but in the context of patriarchy, women's human rights and rampant misogyny in Mozambican society. Evaluations of the historical origins of Mozambican cinema are often void of discussions that delve into the nuanced treatment of women's subjectivities on film. Nonetheless, it is important to understand the origins of a uniquely Mozambican image to come to a uniquely Mozambican argument about how it presents its HIV/AIDS epidemic through cinema.

\section{THEORIZING A MOZAMBICAN WOMEN'S CINEMA}

Since its inception during FRELIMO's armed struggle, Mozambican national cinema has consistently privileged images of women and the participation of women filmmakers in their productions. The revolutionary nation-building aims of the National Institute of Cinema 
necessitated films that showed Mozambicans to themselves and called for all Mozambicans, regardless of gender, to join the collectivist stance against colonial oppression. The development of a national identity that emphasized the equal participation of women and men in all sectors of society was a deliberate attempt to construct a narrative aligned with FRELIMO's

Marxist-Leninist political ideology and a response to colonial-era patriarchal structures.

FRELIMO's promise of the emancipation of women during the armed struggle manifested in the creation of the Mozambican Women's Organization (OMM) and the substantial participation of women in the war. During the OMM's first conference in 1973, Samora Machel, FRELIMO's leader, famously exclaimed that "the liberation of women is a fundamental necessity for the revolution, a guarantee of its continuity and a condition for its success" (Machel 1973; Arnfred 1988, page 5). Film productions during the armed struggle period heavily emphasized the participation of women in guerilla combat and foreign women filmmakers were invited to produce in liberated zones. Most notably amongst them was Margaret Dickinson who directed the documentary Behind the Lines in 1971, where Mozambican women are shown in military uniform training, conversing and unwinding with their male peers. The film showed the postgender revolutionary society promised by Machel, where women fighters were crucial to a successful revolution. The armed struggle era also gave birth to the heroicized image of Josina Machel, which became synonymous with the fight for equitable women's rights and participation of women in society. The politically sound and intellectual image of Josina Machel, was emphasized in some early revolutionary films such as Venceremos (1968) and Mozambique is Our Country (1967). The anniversary of her death, April 7th, is commemorated by the 
celebration of National Women's Day in Mozambique. Despite FRELIMO's successful attempts at mobilizing women for war, the formation of the OMM and films that glorified revolutionary women, Mozambique's 1975 declaration of independence soon revealed the consequences of having constructed a narrative that pledged absolute liberation.

Signe Arnfred, a sociologist commissioned by the OMM in 1983 to conduct interviews with women ex-combatants and revolution participants, published her findings in "Women in Mozambique: Gender Struggle and Gender Politics," where she reveals a stark contrast between FRELIMO's pre-independence promise of emancipation during armed struggle and the return to patriarchal power structures during post-independence nation-state building. During the war, rural and urban women alike were granted leadership roles by the OMM, allowing for increased mobility away from established family patriarchal structures, changing self-perceptions, aspirations, goals and "created the possibility for new gender relations and new female identities" (Arnfred 1988, page 5-6). During the war, FRELIMO had developed a system wherein women facing struggles against male members could petition for support. In Arnred's interview with Habiba, a former provincial representative for the OMM, she recounts a story of a man who was taken to FRELIMO representatives after being accused of beating his wife. Under FRELIMO custody, he was scolded and told "that he shouldn't fight his wife for it was better to fight the Portuguese together". Other war veteran women revealed how the OMM had given passage to autonomous career choices that did not depend on the permission of male family members. Another interviewee, Maria, describes how she divorced her husband and immediately seeked employment and health education in a different village (Arnfred 1988, page 6). 
Other women describe instead a feeling of abandonment by the OMM and a return to patriarchal family structures, where male figures are given control of women's autonomy. Arnred paints a picture of gender relations that were not only returning to how they were before the war, but were instead becoming even more patriarchal: "Men took back what they had lost of patriarchal power. According to women, they took back even more than they had". This conclusion was backed by an interview of a rural woman that described how divorce settlements were changing. Instead of equal division of goods and household utensils, "a husband can divorce his wife for no reason at all, and he'll stay in the house and keep all the goods they have acquired together... she will have to leave the house with nothing at all" (Arnfred 1988, page 7-9). It is also notable that some of the women interviewed by Arnfred who find themselves again stuck in patriarchal families recalled the emancipation promises of FRELIMO.

Simultaneous to Arned's findings in the 1980's, films by the INC had shifted from productions that served as a call to arms and futurist depictions of socialist revolution to nostalgic retellings of FRELIMO's armed struggle era. The INC was still controlled by FRELIMO, who aimed to use their films for the development of a national identity bound to revolutionary struggle. Because Mozambique was being plunged into a brutal civil war, films such as Jose Cardoso's O Tempo dos Leopardos (1982) and Zdravko Velimirović's O Vento Sopra do Norte (1987) instead looked back on FRELIMO's successful armed struggle, a time when Mozambican women were being mobilized, educated, supported and when prospects of transforming gender roles were on the horizon. Towards the end of the decade, the HIV/AIDS epidemic had begun overwhelming Mozambique. Its health system, once a notable success in the 
African continent, began to crumble because of infrastructure and human losses accredited to the Civil War (Bidaurratzaga-Aurre and Colom-Jaén 2012, page 232) Post-independence patriarchal family structures, as described by Arnfred, remained prominent in Mozambican society and only worsened the gender disparity of HIV/AIDS. Mozambican women were marrying older men at younger ages, were pressured to have more children and were educated less than men. By 2003, $18.4 \%$ of Mozambican women were married at age 15 or younger, $55.9 \%$ at age 18 and $74.9 \%$ before they were 20 years old (Clark et al. 2006, page 80). Women married after age 18 receive a mean of 4 years of schooling and those married before age 18 receive a mean of 1.8 years $\underline{\text { (Clark }}$ et al. 2006, page 84). Lack of education means less access to information about the risks of HIV/AIDS, methods of prevention, the availability of seropositive treatment and ultimately leaves women without promising career prospects. Under these patriarchal circumstances, many Mozambican men are the primary money makers in the family and often resort to cross-border migration to neighboring countries as women stay back to care for their children and household. Studies show that migrant men are more likely to engage in risky sexual behaviour, furthering the uncontained spread of HIV (Agadjanian et al. 2011; Hayford et al. 2012). All of these factors, and many other societal ones, contribute to the disparity of HIV prevalence between Mozambican men and women. In 2019, 1.5 million Mozambican women were seropositive, accounting for more than $60 \%$ of the total number of adults living with HIV in the country. HIV prevalence rates for Mozambican adults aged 15-49 stands at 7.3\% of men and $17 \%$ of women (UNAIDS). 
The post-independence entrenched gender disparity in Mozambican society explained by Arnfred in the 1980's through qualitative research is now translatable in quantitative form by epidemiological research of HIV/AIDS. Local and foreign governments, nonprofits and religious organizations have realized that mitigating and preventing its spread means addressing the colonial legacy and its resulting effects on gender disparity first. For filmmakers allocated funding to aid in prevention endeavours, this has given way for a new Mozambican national cinema that offers nuanced narratives of women impacted by HIV/AIDS. The current context in which filmmakers operate represents an opportunity to address the patriarchal systems that were left behind by the colonial era and revise the systems left in place after independence. Up until now, there has never been a push to explore the subjectivities of women in Mozambican cinema without ulterior motives. There are no governmental restrictions on what filmmakers are allowed to produce nor are there significant organizations calling for films that promote Mozambicanness. Even though one can argue that filmmakers are still restricted by their non-profit or humanitarian funding, Mozambican cinema production based on epidemiological data that explicitly uncovers gender disparity has the undoubtable potential of shedding light on a patriarchal society. Moreover, because many of these films are intended for domestic pedagogy, they have the potential to inspire transformative reflection in the Mozambican spectator. Despite being rooted in humanitarianism and epidemiology, the attentiveness HIV/AIDS cinema gives to the nuances of Mozambican women's lives, the absence of government censorship and the newfound autonomy, social assimilation capabilities and creative liberty of women filmmakers working under this context yields an observable Mozambican Women’s Cinema. 


\section{ANALYSING CINEMATIC REPRESENTATIONS OF MOZAMBICAN WOMEN IMPACTED BY HIV/AIDS}

Having theorized a nascent Mozambican women's cinema, it is necessary to utilize knowledge of the historical and contemporary contexts of its development to formulate nuanced visual analyses of films that belong to it and measure their level of success as feminist portrayals of Mozambican women. The contexts that should inform an analysis of Mozambican women's cinema are as follows:

(1) The Portuguese colonial imposition of patriarchal systems and its contemporary legacy. (see page 26)

(2) The history of national Mozambican cinema and its use of images of women. (see pages 14 - 27)

(3) The debated success of FRELIMO's promise of women's emancipation during the armed struggle. (see pages 38 - $39 \&$ Arnfred 1988)

(4) The observable gender disparities in HIV/AIDS epidemiology and its causes (see page $40 \&$ Bidaurratzaga-Aurre and Colom-Jaén 2012; Clark 2006)

(5) The production processes and aims of pedagogical humanitarian cinema (see pages 29 - 37)a 
Analysis of Another Man's Garden. One of the most notable examples of HIV/AIDS narrative cinema from Mozambique is Sol de Carvalho's feature-length film, O Jardim do Outro Homem (Another Man's Garden). The film received substantial distribution abroad with the purpose of re-compensating its 400,000 Euro budget and showcasing the humanitarian agenda of the organizations involved. Most importantly, it received and continues to receive extensive distribution within urban and rural Mozambique. Using a combined funding pool from NGOs, international cinema funds, foreign and local government initiatives and grassroots campaigns, Another Man's Garden demonstrates how HIV/AIDS cinema enacts negotiations between adapting to a uniquely Mozambican context, asserting its autonomy as an authentic depiction of impacted subjectivities and its subordination in the form of the imposition of the humanitarian agendas of foregin organizations.

Another Man's Garden intimately explores the nuances of a young woman in Mozambique and therefore explores the clashes between the transforming nature of Mozambican youth sexual practices (Karlyn 2005), disproportionate HIV/AIDS rates amongst young women and the conservative patriarchal and misogynistic structures embedded into society and institutions. Its title comes from a Mozambican proverb which metaphorically proclaims that sending a girl to school is like watering another man's garden, signaling a cultural prejudice rooted in patriarchy. The film embeds complex questions that affect the lives of millions of Mozambicans through the subjectivity of its protagonist, 19 year old public school student Sofia Macuacua, portrayed by Mozambican actress Gigliola Zacara. In a telling scene, Sofia’s grandmother utters the titular words to her in Portuguese. Despite speaking the local Changana 
language throughout with her family the film amongst each other, the scene is evident of a prevalent cross-generational divide, especially between older and younger women. Not only does the scene offer context to the title of the film, it is a testament to the fact that anyone who is an older woman in Mozambique lived through the country's colonial period where Portuguese was imposed, Mozambique's independence war, subsequent civil war and the advent of all public health crises that disproportionately affect women and girls all of which worked to cement power imbalance between genders.

In order to achieve her goals of gaining admission to an Undergraduate program of Medicine at a national university to become a nurse, Sofia confronts serious personal and bureaucratic hurdles. She is from a low-income family that consists of all women; her older sister, mother and grandmother. As a family, they make a living off stone breaking, reference to the prevalence of manual labour as income generating sources and the familial structures that support it. Her father has abandoned them to work at a mine in South Africa, where he has started a new family, a sub-narrative plot that hints at indicates a prevalent migratory pattern across Mozambique, which in turn has led to increased rates of HIV transmission due to extra-marital sex, prostitution and sexual assault in Mozambique's cross-border mining section (Barwise et al. 2013). Moreover, she is consistently confronted by her elder sister, mother and grandmother who do not see value in her educational pursuits and thus, see no value in doling out family funds to pay for her school fees, equipment and uniforms. Consequently in one instance, Sofia arrives at school not wearing the required uniform. She is reprimanded by a male professor and summoned to his office, where she is accosted and sexualized by him. The scene 
implicitly describes a linkage between poverty and sexual assault. Attentiveness is then played on the dialogue between Sofia and her female peers, where she explains the reasoning behind rejecting advances. In essence, she describes her wishes of autonomy in pursuit of higher education.

Her male teacher is shown sexually preying on his young female pupils by offering good and passing grades in exchange for sexual favors. Sofia continuously refuses, a move that sets the stage for the adversity she faces to reach her goals and distinguishes her as a protagonist who is sternly against succumbing to traditional gender norms. Besides refusing herself, Sofia mentors her peers on her wishes of self-governance. These social interactions that emphasize Sofia's conceptualizations of systematic abuse in her institution serve to further distance HIV/AIDS prevention methods as mere medicinal processes. Instead, uplifting peers, standing up against patriarchal systems and creating safe communication spaces for women are shown as a crucial intersection in the fight against HIV/AIDS that does not at all relate to personal and institutional medicinal processes.

Personal romantic relationships and patterns of intimacy amongst youth in Mozambique have been transforming in recent years, owing to the advent of foreign media, digitalization and globalization (Karlyn 2005, pg. 278). Sofia becomes enamored with an older boy who plays football, entering a romantic relationship that quickly turns sexual. His character represents cross-generational machismo in Mozambican culture, and simultaneously a new generational uptick in pre-marital sex (Karlyn 2005). It is then Sofia, not her boyfriend, that pushes for him to wear a condom during prolongated and emphasized sex scenes. The purpose of these scenes is 
to to viscerally depict recreational, consensual sex and propose (or promote) a ritual of safe sex where the male partner wears a condom and the female parter has the autonomy to enforce it. Sofia enforces her partner to wear a condom multiple times, verbally expressing that her educational pursuits come first before bringing a child into the world. Her determination and perseverance to keep sexual encounters safe and recreational fosters resentment in her partner, causing a dissolution of the relationship. Nonetheless and against the harsh criticism of her family, Sofia continues the pursuit of her education. For young female Mozambican spectators, the melodramatic narrative structuring of Sofia's romantic relationship is a familiar one yet ultimately disrupted as Sofia's autonomous educational dreams persist. Sofia's ultimate decisive and conscious dissevering with patriarchy and the systems that uphold it that form the film's denouement. Whether it is speaking up against systematic oppression at school, or the personal choices she makes to enforce her partner to stay protected during intercourse, Sofia's character receives a positive ending. The final scenes offer a flash-forward of Sofia in doctor's garb, accompanied by other female coworkers. The scene serves to transmit to its audience a hopeful image of a new Mozambique in the years to come. Sol de Carvalho manages his objective, not only showing the devastation of HIV/AIDS on Mozambican communities and families, but affectively exposing the intricate interconnections with institutional, intrapersonal, interpersonal and familial patriarchal structures and increasingly gender-disproportionate rates of transmission through familiar narrative structures. In films that aim to target vulnerable young audiences, it is imperative that importance is given to the social construction of diseases in Mozambique and to approaches that confront the crisis with an 
interdisciplinary and ample lens. Sofia's story in Another Man's Garden aims to cultivate uniquely Mozambican spectatorial introspection into the contradictory relationship between a heavily patriarchal society, where male imposition towards women in all facets of society still runs rampant, and a globalizing youth amidst the nascent world of conquesting women's human rights.

\section{A NEW WAVE OF MOZAMBICAN WOMEN FILMMAKERS PRODUCING UNDER THE CONTEXT OF HIV/AIDS}

Women filmmakers are in an arguably better position under a privatized Mozambican film industry. Unlike its socialist origins, the image of Mozambican women is no longer hyper-controlled by a state attempting to unify and portray fallacies of gender equality as result of policy implementation. HIV/AIDS is a context that especially asks for films that pay nuanced attention to Mozambican female subjectivities and to create narrative profiles that do not focus solely on medical mitigation and prevention tactics. In other words, women filmmakers working under the HIV/AIDS context are now at liberty to attempt re-structuring, re-interpreting Mozambican women by addressing the previously invisible patriarchal dimensions that suppress them. Karen Boswell, albeit a British national, is known for her documentary work in Mozambique. Her status as a woman filmmaker allows for interpersonal relationships between her and her subjects that unravel deeply personal, yet simultaneously conversational, individual voices to shine. 
Mozambican-born Isabel Noronha is a pioneer of feminist filmmaking in Mozambique. Like most Mozambican filmmakers, her career began under INC employment, where she played a leading role in the production of several Kuxa Kanema news reels. Professionally, she is a trained psychologist and has continued producing films in Mozambique. With the unravelling of the INC and a nationalized media in the country, Noronha has continued producing films as a freelancer. Her films can be described as experimental creative documentaries, as they often involve conversations with her subjects. Her short film Mother of Grandchildren (2007) features a claymation reconstruction of real-footage, and tells the story of a grandmother who cares for eight children following the death of their father. It thematically delves into the impacts of HIV/AIDS related deaths in traditional family structures. Esmael Alves de Oliveira argues that Noronha's film is an especially important and unique contribution to depictions of HIV/AIDS in Mozambican cinema. For Noronha, he argues, "the body is beyond dualistic and essentialist... it is a social construct", evident in the presentation of the body as liminal through the use of claymation (de Oliveira, page 3). Her intimate interactions with her subject are revealed in the interview with "the grandmother" in the short film, and her conceptualizations of HIV/AIDS that transgress the physical body are revealed. The reconstruction of real-life footage with clay accompanied with the solemn interview audio reveals how corporal practices and habits translate the social positioning of subjects within objective social classifications, in this case, an older woman impacted by a death related HIV/AIDS now once again under the classification of "mother". Noronha demonstrates that the female body is first social before it is natural, and therefore does not need to delve into conversations of the disease in relation to the medicinal. 
Her newest published project is A Trilogia das Novas Famílias (2008) [A Trilogy of New Families] which chronicles three fatherless families from across the country. Her approach is once again a distancing from the medical takeaways of HIV/AIDS cinema, and can be summarized as a meditation on new matriarchal and cross-generational family structures that resulted from losses to AIDS. Once again, she emphasized on the liminality of the body, now presented as a clash between the social construct of traditional patriarchal family structures, new familial hierarchies led by women and children and the physical hindrances of manual labour. Isabel Noronha's work is part of an emerging group of Mozambican women filmmakers who despite working under the limitations of HIV/AIDS prevention, poverty curbing and humanitarian funding, manage to promulgate fresh interpretations of invisible structures of patriarchy and its impact to Mozambican women.

\section{CONCLUSION}

This paper attempted first to include representations of Mozambique's HIV/AIDS epidemic into the discourse of the country's national revolutionary cinema origins. Through the unravelling of parallels and left-over traditions of filmmaking, new processes of production, distribution and spectatorship of HIV/AIDS cinemas were explicated. The fallacy of feminism as inherent to Mozambique's socialist uprising left for unnuanced images of Mozambican women that nonetheless managed to shape contemporary ideas of a completed women's liberation in the country. 
Curtailing the gender-disproportionate figures of HIV/AIDS transmission in the country was a call to action for Mozambican filmmakers to act on available funding in order to attempt refined representations of women's subjectivities through film. Though some films manage international distribution for fundraising purposes, the intended distribution of HIV/AIDS cinema is predominantly domestic, regardless of the transnational collaborations necessary to produce a film. In other words, the films are made with the aim of distributing them within Mozambique, targeting especially the youth demographic. Distribution is arguably just as important as production for these films, yet it functions distinctly to say an art film, or a narrative film that would hope to be screened at film festivals all over the world as representative of the Mozambican cinema industry. HIV/AIDS films are not concerned with an international audience, or to stand in as Mozambican cinema in an African film festival. Instead, they hope to be another tool of communicating holistic and sustainable societal shifts to mitigate and prevent the spread of HIV/AIDS through personal behavioural adaptations. By focusing in on women as protagonists, the films do not only reveal methods of preventing a sexually transmitted infection but also a feminist message that calls for a restructuring of existing systems of patriarchy and embeded misogyny with community action. In the end, the geographical vastness of Mozambique, the multitude of languages and ethnicities represented, calls for an acceptance of the uniqueness of production, distribution and spectatorial processes and patterns of HIV/AIDS cinema(s) from Mozambique. 
Works Cited

Agadjanian, Victor, et al. "Health Costs of Wealth Gains: Labor Migration and Perceptions of HIV/AIDS Risks in Mozambique.” Social Forces; a Scientific Medium of Social Study and Interpretation, vol. 89, no. 4, June 2011, pp. 1097-1117.

Agadjanian, Victor, and Cecilia Menjívar. "Talking about the 'Epidemic of the Millennium': Religion, Informal Communication, and HIV/AIDS in Sub-Saharan Africa." Social Problems, vol. 55, no. 3, [Oxford University Press, Society for the Study of Social Problems], 2008, pp. 301-321.

Alexandre, Valentim. “Ideologia, Economia E Política: A Questão Colonial Na Implantação Do Estado Novo.” Análise Social, vol. 28, no. 123/124, Instituto Ciências Sociais da Universidade de Lisboa, 1993, pp. 1117-1136.

Andrade-Watkins, Claire. "Portuguese African Cinema: Historical and Contemporary Perspectives: 1969 to 1993.” Research in African Literatures, vol. 26, no. 3, Indiana University Press, 1995, pp. 134-150.

Ayisi, Florence, and Catalin Brylla. "The Politics of Representation and Audience Reception: Alternative Visions of Africa." Research in African Literatures, vol. 44, no. 2, Indiana University Press, 2013, pp. 125-141. 
Bamba, Mahomed. "In the Name Of'cinema Action'and Third World: The Intervention of Foreign Film-Makers in Mozambican Cinema in the 1970s and 1980s." Journal of African Cinemas, vol. 3, no. 2, Intellect, 2012, pp. 173-185.

Bidaurratzaga-Aurre, Eduardo, and Artur Colom-Jaén. "HIV/AIDS Policies in Mozambique and the New Aid Architecture: Successes, Shortcomings and the Way Forward.” The Journal of Modern African Studies, vol. 50, no. 2, Cambridge University Press, 2012, pp. $225-252$.

---. "HIV/AIDS Policies in Mozambique and the New Aid Architecture: Successes, Shortcomings and the Way Forward." The Journal of Modern African Studies, vol. 50, no. 2, Cambridge University Press, 2012, pp. 225-252.

Cinemovel Foundation. https://cinemovel.tv/eng/page/3/. Accessed 16 Mar. 2021.

Clark, Shelley, et al. "Protecting Young Women from HIV/AIDS: The Case against Child and Adolescent Marriage." International Family Planning Perspectives, vol. 32, no. 2, June 2006, pp. 79-88.

---. "Protecting Young Women from HIV/AIDS: The Case against Child and Adolescent Marriage.” International Family Planning Perspectives, vol. 32, no. 2, June 2006, pp. $79-88$.

---. "Protecting Young Women from HIV/AIDS: The Case against Child and Adolescent Marriage." International Family Planning Perspectives, vol. 32, no. 2, June 2006, pp. $79-88$. 
CONSELHO NACIONAL DE COMBATE AO HIV/SIDA. ESTRATÉGIA NACIONAL DE COMUNICAÇÃO PARA O COMBATE AO HIV/SIDA. Vol. 1, 1, CONSELHO NACIONAL DE COMBATE AO HIV/SIDA, June 2006, p. 75, https://www.ilo.org/wcmsp5/groups/public/---ed_protect/---protrav/---ilo_aids/documents /legaldocument/wcms_172573.pdf.

de Carvalho, Sol. "Falta Dinheiro Para o Nosso Cinema Explodir.” domingo, Entrevista, no. September 16, 2019, 16 Sept. 2019, pp. 16-18.

de Oliveira, Alberto Gomes, et al. "O PEDAGÓGICO EM O JARDIM DO OUTRO HOMEM, DE SOL DE CARVALHO.” Revista Mulemba, vol. 5, no. 9, Nov. 2013, https://revistas.ufrj.br/index.php/mulemba/article/view/4981/16142.

de Oliveira, Esmael Alves. O Corpo No Cinema Moçambicano: Uma Análise Da Experiência Do HIV/AIDS a Partir Das Obras Cinematográficas de Isabel Noronha E Orlando Mesquita.

de Oliveira Simone Becker, Esmael Alves. "POR UMA CORPOREIDADE DAS IMAGENS: ALGUMAS REFLEXÕES (IN)DISCIPLINADAS SOBRE CORPO, GÊNERO E SAÚDE NO CINEMA MOÇAMBICANO FOR A CORPOREITY OF THE IMAGES: SOME (IN)DISCIPLINED REFLECTIONS ABOUT THE BODY, GENDER, AND HEALTH IN THE MOZAMBICAN CINEMA.” RAIDO - Revista Do Programa de Pos-Graduação Em Letras Da UFGD, Dec. 2018, p. 17. 
del Sarto, Ana. "Cinema Novo and New/Third Cinema Revisited: Aesthetics, Culture and Politics." Chasqui, vol. 34, Chasqui: revista de literatura latinoamericana, 2005, pp. 78-89.

El-Khawas, Mohamed A. "PROBLEMS OF NATION-BUILDING IN MOZAMBIQUE.” The Black Scholar, vol. 11, no. 5, Taylor \& Francis, Ltd., 1980, pp. 24-36.

Eshun, Kodwo, and Ros Gray. "The Militant Image: A Ciné-Geography: Editors' Introduction." Third Text, vol. 25, no. 1, Taylor \& Francis, 2011, pp. 1-12.

Gallagher, Tom. “Controlled Repression in Salazar's Portugal.” Journal of Contemporary History, vol. 14, no. 3, Sage Publications, Ltd., 1979, pp. 385-402.

Graça Machel Mandela Parla Di Cinemovel. 14 Jan. 2014, https://cinemovel.tv/graca-machel-mandela/.

Gray, Ros. "Cinema on the Cultural Front: Film-Making and the Mozambican Revolution." Journal of African Cinemas, vol. 3, no. 2, ingentaconnect.com, 2012, pp. 139-160.

---. Cinemas of the Mozambican Revolution: Anti-Colonialism, Independence and Internationalism in Filmmaking, 1968-1991. Boydell \& Brewer, 2020.

---. “Haven’t You Heard of Internationalism?: The Socialist Friendships of Mozambican Cinema." Postcommunist Film - Russia, Eastern Europe and World Culture: Moving Images of Postcommunism, Routledge, 2013.

---. “'Haven’t You Heard of Internationalism?': Ros Gray.” Postcommunist Film-Russia, Eastern Europe and World Culture, Routledge, 2013, pp. 67-88. 
---. Third Cinema: Filming the Revolution in Mozambique. research.gold.ac.uk, 2007, http://research.gold.ac.uk/id/eprint/11965.

Hayford, Sarah R., et al. "Now or Never: Perceived HIV Status and Fertility Intentions in Rural Mozambique." Studies in Family Planning, vol. 43, no. 3, Sept. 2012, pp. 191-199.

Israel, Paolo. “Feminist Masquerades and Women's Liberation, Nangade, Mueda, Muidumbe, 1950s-2005." Kronos , no. 39, University of Western Cape, 2013, pp. 204-229.

---. "The Liberation Script in Mozambican History." Kronos , no. 39, University of Western Cape, 2013, pp. 10-19.

Joffe, Avril, and Natalie Jacklin. Promoting the Culture Sector through Job Creation and Small Enterprise Development in SADC Countries: The Film and Television Industry. 53, International Labour Office, 2003, https://www.ilo.org/wcmsp5/groups/public/@ed_emp/@emp_ent/@ifp_seed/documents/ publication/wcms_117678.pdf.

Karlyn, A. S. "Intimacy Revealed: Sexual Experimentation and the Construction of Risk among Young People in Mozambique." Culture, Health \& Sexuality, vol. 7, no. 3, May 2005, pp. 279-292.

Lloyd, Robert B., et al. Lessons from Uganda, Mozambique and Ethiopia. 1st ed., Bristol University Press, 2019.

Loftus, M. "Kuxa Kanema: The Rise and Fall of an Experimental Documentary Series in Mozambique.” Journal of African Cinemas, ingentaconnect.com, 2012, https://www.ingentaconnect.com/content/intellect/jac/2012/00000003/00000002/art00003 
Manuel, Sandra. “Obstacles to Condom Use among Secondary School Students in Maputo City, Mozambique.” Culture, Health \& Sexuality, vol. 7, no. 3, May 2005, pp. 293-302.

McGuffie, Allison Doris. African Educational Film and Video. The University of Iowa, 2018, doi:10.17077/etd.9v8xzqkz.

Meleiro, Alessandra. "Luso-African Cinema: Nation and Cinema." Journal of African Cinemas, vol. 3, no. 2, africabib.org, 2011, pp. 133-249.

Moszynski, Peter. "Donor Fatigue Is Slashing Access to AIDS Care in Africa, Warns Charity." $B M J$, vol. 340, May 2010, p. c2844.

“Mozambique.” UNAIDS, https://www.unaids.org/en/regionscountries/countries/mozambique. Accessed 19 May 2021.

Oliveira, Esmael Alves de. Qualquer semelhança não é mera coincidência: uma análise do HIV/AIDS no cinema moçambicano. 2014, https://repositorio.ufsc.br/handle/123456789/128871.

Pasley, Victoria. "Kuxa Kanema. Third Cinema and Its Transatlantic Crossings.” Rethinking Third Cinema. The Role of Anti-Colonial Media and Aesthetics in Postmodernity, 2009, pp. $107-123$.

Pereira, Cristiana. "A função provocadora do artista, entrevista a Sol de Carvalho.” Buala.org, Buala, 28 Jan. 2011, https://www.buala.org/pt/cara-a-cara/a-funcao-provocadora-do-artista-entrevista-a-sol-decarvalho. 
Power, Marcus. "Post-Colonial Cinema and the Reconfiguration of Moçambicanidade." Médias, Pouvoir et Identités, vol. 26, no. 3, KARTHALA Editions, 2005, p. 261.

RayRay-Ntsane, Alosha, and Simon Chislet. Steps for the Future - Facilitator's Guide. 2nd Edition, Social Transformation and Empowerment Projects (STEPS), 2007, http://steps.co.za/wp-content/uploads/2017/08/STFT-Guides.pdf.

Rolletta, Paola. "Filme Sobre Sida (Aids) Marca Volta Do Cinema Moçambicano às Salas." Swissinfo.ch, 27 Feb. 2007, https://www.swissinfo.ch/por/filme-sobre-sida--aids--marca-volta-do-cinema-mo $\% \mathrm{C} 3 \% \mathrm{~A}$ 7ambicano-\%C3\%A0s-salas/5708308.

Scranton, Jessica. INTEGRATING GENDER AND GBV INTO HIV PREVENTION

PROGRAMMING IN MOZAMBIQUE. Family Health International 360 (FHI 360), 2016, https://www.fhi360.org/sites/default/files/media/documents/resource-spt-cap-mozambiqu e-gbv-integration.pdf.

Seabra, Jorge (coord ). "Cinemas Em Português: Moçambique, Auto E Heteroperceções.” Imprensa Da Universidade de Coimbra, 2018.

Signe Arnfred. "Women in Mozambique: Gender Struggle and Gender Politics.” Review of African Political Economy, no. 41, [ROAPE Publications Ltd, Taylor \& Francis, Ltd.], 1988, pp. 5-16.

Solanas, Fernando, and Octavio Getino. "TOWARD A THIRD CINEMA.” Cinéaste, vol. 4, no. 3, Cineaste Publishers, Inc, 1970, pp. 1-10. 
Sousa, Helena. The Mobilization of the "Lusophony" Concept : The Case of RTP International Channels. unknown, July 2005, http://dx.doi.org/.

STEPS For The Future : 21 Apr. 2013, https://archive.ph/20130421225127/http://www.stepsforthefuture.co.za/films more.php?i $\underline{\mathrm{d}=273}$.

Stollery, Martin, and Peter Lev. "College Course File: THE QUESTION OF THIRD CINEMA: AFRICAN AND MIDDLE EASTERN CINEMAS.” Journal of Film and Video, vol. 52, no. 4, University of Illinois Press, 2001, pp. 44-55.

Ukadike, Nwachukwu Frank. Black African Cinema. University of California Press, 1994.

Vieira, Marco Antonio. “Southern Africa’s Response(s) to International HIV/AIDS Norms: The Politics of Assimilation." Kokusaigaku Revyu = Obirin Review of International Studies, vol. 37, no. 1, Cambridge University Press, 2011, pp. 3-28.

WHO | Definitions: Emergencies. World Health Organization, Nov. 2014, https://www.who.int/hac/about/definitions/en/.

\section{FILMOGRAPHY}

25 (1975). Direction: José Celso and Celso Lucas, colour, SNS, Mozambique

Behind the Lines (1971). Direction: Margaret Dickinson, 50 mins, colour 35mm, Company Films, United Kingdom, Mozambique.

Dancing on the Edge (2001). Direction: Karen Boswall, 42 mins, colour video, Steps for the Future, Mozambique 
Do Rovuma ao Maputo (1975). Direction: Dragutin Popović, black and white 35mm, Filmske Novosti, Yugoslavia/SNC, Mozambique.

A História de um Mineiro (2001). Direction: Gabriel Mondlane and Nic Hofmeyer, video, South Africa/Mozambique.

Hóspedes da Noite (2007). Direction: Licínio Azevedo, 57 mins, colour, Ébano Films, Mozambique

I vårt land börjar kulorna blomma (1971). Direction: Lennart Malmer and Ingela Romane, colour, Sveriges Radio AB, Sweden.

Kuxa Kanema (1978-1985). Direction: various, approx. 10 mins, black and white 16mm. A Luta Continua (1972). Direction: Robert Van Lierop, 36 mins, 16mm, African Information Unit, USA/Mozambique

Moçambique em progresso sob a direcção do Presidente Samora Moisés Machel (1981).

Direction: unknown. North Korea/Mozambique

Mueda, Memória e Massacre (1979). Direction: Ruy Guerra, 80 mins, black and white, 16mm, INC, Mozambique

Nachingwea: a intelligência e a māo (1975). Direction: Dragutin Popović. Black and white, Filmske Novosti, Yugoslavia/CNS, Mozambique

No Jardim do Outro Homem (2006). Direction: Sol de Carvalho, colour 35mm, Fado Films, Portugal/Films du Mai, France/Promarte, Mozambique

The People of Mozambique are Fighting On (1971) Direction: Tan Qi. China/Frelimo, Mozambique 
Televisão nos bairros (1981). Direction: Moira Forjaz and Licinio Azevedo, TVE, Mozambique. True Friends (2002). Direction: Bert Sonnenschein, 21 minutes, colour video, Steps for the

Future, Mozambique

O Tempo dos Leopardos (1985). Direction: Zdravko Velimirović, 91 mins, colour 35mm, Avala

Films, Yugoslavia/INC, Mozambique

Venceremos (1968). Direction: Dragutin Popović, 30 mins, black and white, Filmske Novosti, Yugoslavia/Frelimo, Mozambique

Viva Frelimo! (1971), Direction: Yuri Egorov and Leonid Maksimov, 17 mins, colour 35mm, USSR/Frelimo, Mozambique

O Vento Sopra do Norte (1985), Direction: José Cardoso, 100 mins, black and white 16mm, INC, Mozambique 


\section{Bibliography}

Ayisi, Florence, and Catalin Brylla. "The Politics of Representation and Audience Reception: Alternative Visions of Africa." Research in African Literatures, vol. 44, no. 2, Indiana University Press, 2013, pp. 125-141, doi:10.2979/reseafrilite.44.2.125.

Bleiker, Roland, and Amy Kay. "Representing HIV/AIDS in Africa: Pluralist Photography and Local Empowerment." International Studies Quarterly: A Publication of the International Studies Association, vol. 51, no. 1, [International Studies Association, Wiley], 2007, pp. 139-163, http://www.jstor.org/stable/4621705.

Davis, Julia. Evolution of an Epidemic: 25 Years of HIV/AIDS Media Campaigns in the U.S. Report. Kaiser Family Organization, June 2006, https://www.kff.org/wp-content/uploads/2013/01/7515.pdf.

Ellerson, Beti. “Teaching African Women in Cinema: Part Two.” Black Camera, vol. 7, no. 2, Indiana University Press, 2016, pp. 217-233, doi:10.2979/blackcamera.7.2.217.

Foreit, K. F., et al. "Population Movements and the Spread of HIV/AIDS in Mozambique." Journal of Health and Human Services Administration, vol. 24, no. 3, Winter 2001, pp. 279-294, https://www.ncbi.nlm.nih.gov/pubmed/14998285.

Gerhart, Gail. “Independence Comes to Mozambique.” Africa Today, vol. 22, no. 3, Indiana University Press, 1975, pp. 11-14, http://www.jstor.org/stable/4185517.

Gupta, Pamila, and Estienne Rodary. "Opening-up Mozambique: Histories of the Present.” African Studies, vol. 76, no. 2, Routledge, Apr. 2017, pp. 179-187, doi:10.1080/00020184.2017.1322865. 
Haacker, Markus. "Framing AIDS as an Economic Development Challenge." The Brown Journal of World Affairs, vol. 17, no. 2, Brown Journal of World Affairs, 2011, pp. 65-76, http://www.jstor.org/stable/24590795.

Haugen, Caitlin S., et al. "Increasing the Number of Female Primary School Teachers in African Countries: Effects, Barriers and Policies." International Review of Education / Internationale Zeitschrift Für Erziehungswissenschaft / Revue Internationale de l'Education, vol. 60, no. 6, Springer, 2014, pp. 753-776, http://www.jstor.org/stable/24637078.

Jamieson, Jeremy P., and Stephen G. Harkins. "The Effect of Stereotype Threat on the Solving of Quantitative GRE Problems: A Mere Effort Interpretation.” Personality \& Social Psychology Bulletin, vol. 35, no. 10, Oct. 2009, pp. 1301-1314, doi:10.1177/0146167209335165.

Levi, Pavle. "Aesthetics of Nationalist Pleasure." Disintegration in Frames: Aesthetics and Ideology in the Yugoslav and Post-Yugoslav Cinema, edited by Stanford University Press, Stanford University Press, 2007, pp. 87-108.

Mckay, Ramah. "Documentary Disorders: Managing Medical Multiplicity in Maputo, Mozambique." American Ethnologist, vol. 39, no. 3, Wiley, 2012, pp. 545-561, http://www.jstor.org/stable/23250784. 
Med Hondo, Scott Mckenzie. "WHAT IS THE CINEMA FOR US? (Mauritania, 1979).” FILM MANIFESTOS AND GLOBAL CINEMA CULTURES A Critical Anthology, 2014, doi:978-0-520-27674-1 (.

Murphy, David. “Africans Filming Africa: Questioning Theories of an Authentic African Cinema." Journal of African Cultural Studies, vol. 13, no. 2, Routledge, Dec. 2000, pp. 239-249, doi:10.1080/713674315.

Naficy, Hamid. “Under Cover, on Screen: Women's Representation and Women's Cinema." $A$ Social History of Iranian Cinema, Volume 4: The Globalizing Era, 1984-2010, Duke University Press, 2012, pp. 93-175.

O’Donnell, Thomas J. "Salazar and the New State of Portugal." Studies: An Irish Quarterly Review, vol. 25, no. 97, Irish Province of the Society of Jesus, 1936, pp. 131-144, http://www.jstor.org/stable/30097310.

Parks, Thomas. "The Rise and Fall of Donor Funding for Advocacy NGOs: Understanding the Impact.” Development in Practice, vol. 18, no. 2, [Taylor \& Francis, Ltd., Oxfam GB], 2008, pp. 213-222, http://www.jstor.org/stable/27751904.

Schneider, Kammerle, and Laurie A. Garrett. The Evolution and Future of Donor Assistance for HIV/AIDS. Council on Foreign Relations, 2009, doi:10.2307/resrep24167.

Seckinelgin, Hakan. "Who Can Help People With HIV/AIDS in Africa? Governance of HIV/AIDS and Civil Society." Voluntas: International Journal of Voluntary and 
Nonprofit Organizations, vol. 15, no. 3, Springer, 2004, pp. 287-304, http://www.jstor.org/stable/27927921.

Sparks, Colin. "Global Media Studies: Its Development and Dilemmas." Media Culture \& Society, vol. 35, no. 1, SAGE Publications Ltd, Jan. 2013, pp. 121-131, doi:10.1177/0163443712464566.

Stam, Robert. "Beyond Third Cinema: The Aesthetics of Hybridity." Rethinking Third Cinema, edited by Anthony Guneratne Wimal Dissanayake, 2004.

Strategies for Hope Trust. "Churches in Mozambique Using 'What Can I Do?'” Strategies for Hope, 2019, http://www.stratshope.org/partners/partners_users_item/churches-all-over-mozambique-u sing-what-can-i-do.

Vučetić, Radina. "We Shall Win: Yugoslav Film Cooperation with FRELIMO.” Revista Critica de Ciencias Sociais, no. 118, May 2019, pp. 131-150, doi:10.4000/rccs.8652.

White, Patricia, editor. "Is The Whole World Watching? Fictions of Women's Rights." Women's Cinema, World Cinema, Duke University Press, 2015, pp. 168-181. 